Ю. В. Датченко

\title{
ЛЕКСИКА ПИСАНКАРСТВА ЯК ВІДОБРАЖЕННЯ МОВНО-КУЛЬТУРНОГО ФЕНОМЕНА УКРАЇНЦІВ
}

Датченко Ю. В. Лексика писанкарства як відображення мовно-культурного феномена українців.

У статті зроблено огляд різних підходів до культурно маркованих слів, запропоновано розглядати лексику писанкарства як національно марковану, виділено особливості різних груп лексики писанкарства, що відображають унікальність світосприйняття українців.

Ключові слова: етнолінгвістика, лексика писанкарства, національнокультурний компонент, культурно марковані одиниці.

Датченко Ю. В. Лексика писанкарства как отражение культурно-языкового феномена украинцев.

В статье сделан обзор разных подходов к культурно-маркированым словам, предложено рассматривать лексику писанкарства как культурно-маркированную, выделены особенности разных групп лексики писанкарства, отображающие уникальность мировосприятия украинцев.

Ключевые слова: этнолингвистика, лексика писанкарства, национальнокультурный компонент, культурно маркированные единицы.

Datchenko U. Vocabulary Easter eggs as a reflection of cultural and linguistic phenomenon of Ukrainians.

The article provides an overview of different approaches to cultural and bulleted words, proposed to consider language as a cultural and Easter eggs labeled highlighted features of different language groups Easter eggs, displays the unique worldview of the Ukrainians.

Key words: ethnolinguistics, vocabulary of Easter eggs, national and cultural component, in a civilized manner marking units.

Дослідження взаємозв'язку мови й культури є одним із актуальних напрямків сучасної лінгвістики. Значну кількість слів, що містять інформацію про культуру певної країни, розглядають у межах різних наук, а саме: 3 лінгвістичного погляду (реалї, культурно-маркована лексика, лексика з культурним компонентом, культурологічна лексика), в перекладознавстві (безеквівалентна лексика), у культурознавстві (конщепти, фрейми), з погляду психолінгвістики (прототипи) тощо.

Особливості унікальної народної культури можна вивчати крізь ๑ Ю. В. Датченко, 2015. 
національну мову, що акумулювала культурні цінності й світогляд нації. Це підвищило інтерес дослідників до лексики, що містить національнокультурний компонент. Етнолінгвістичний напрям, орієнтований на реконструктивний план виявлення культурних шарів у формуванні лексичного фонду національних мов, має витоки в працях Ф. Боаса, Е. Сепіра, О. Потебні. Опис культурно маркованих номінативних одиниць, аналіз їхніх ареальних особливостей, дослідження етнічних символів, стереотипів, міфологем активно вивчається в сучасному українському мовознавстві (В. Ужченко, О. Селіванова, П. Гриценко, Н. Хозбей, В. Жайворонок, М. Кочерган, В. Манакін, Н. Сукаленко й ін.).

3 прадавніх часів в українській мові сформувався значний пласт професійної лексики писанкарства, яка ввібрала в себе народний досвід освоєння природних матеріалів і пристосування їх до задоволення релігійних і обрядових потреб людини. Писанкарська термінологія, як і технічні прийоми роботи стародавнього ремесла, мовби найдорожчий скарб передавалася від роду до роду, успадковувалася й збагачувалася кожним наступним поколінням мистців. У ній ще й досі зберігаються архаїчні елементи язичницького світосприйняття, що сягають своїми витоками до найдавніших археологічних культур. Тому вивчення писанкарської лексики важливе не лише для мовознавства, а й для пізнання джерел формування й особливостей історичного розвитку української культури загалом, з'ясування етногенези, етнічної історії українців. На жаль, лексика писанкарства не була предметом дослідження мовознавців і залишалася поза увагою дослідників.

Отже, актуальність теми дослідження зумовлена загальним спрямуванням лінгвістичних досліджень на виявлення етноспецифічного компоненту в національно-мовній картині світу. Опрацювання культурно маркованих одиниць як носія культурної інформації на матеріалі лексики писанкарства відповідає настановам сучасних лінгвокультурологічних студій щодо опрацювання проблем лексичної семантики в антропоцентричному руслі. Мета дослідження полягає у виявленні особливостей різних груп лексики писанкарства, що відображають мовно-культурний феномен українців.

Об'єктом дослідження є лексика писанкарства, яка відображає фрагменти української національно-мовної картини світу. У нашому дослідженні і мова, і культура розглядаються в межах етногенезу, тобто у зв'язку 3 розвитком етносу, що формує їх. Мова виступає як універсальний компонент культури, продукт і умова іiі існування один 3 каналів трансляції етнокультурної інформації. Відомо, що слово є 
основною одиницею мови, в якій відображається культура. Сприйняття певної лексики значною мірою допомагає оволодіти словами, своєрідна семантика яких відображає своєрідність культури народу. За визначенням Є. Верещагіна й В. Костомарова такі слова називаються культурним компонентом мови. Вони містяться на перетині мови й культури [1].

Дослідження культурно маркованих феноменів, до яких належить $\mathrm{i}$ лексика писанкарства, грунтується на розумінні онтологічної єдності мови і культури як у функціональному, так і в генетичному аспектах. Культуру можна тлумачити як сукупність матеріальних i духовних артефактів людської діяльності, відображених в системі знаків, символів і норм, що історично передаються і відтворюються певною етнічною спільнотою. Оскільки писанкарство є невід’ємною частиною української культури, культурно марковані одиниці потребують докладного опрацювання.

Тлумачення лексеми «писанка» подається в багатьох словниках, зокрема у словнику-довіднику «Знаки української етнокультури» В. Жайворонка міститься таке пояснення: «розмальоване великоднє куряче або декоративне, звичайно дерев'яне, яйце; розписується різноманітними орнаментом - геометричним, рослинним, тваринним; кожен колір у писанковому розпису має власну символіку; розписане яйце символізує джерело життя, усього живого; звичай розмальовувати писанки походить ще 3 дохристиянських часів; здавна писанки наділялися охоронними властивостями» [2, с. 450-451]. Як бачимо, науковець вказує на певні елементи, які відображають світосприйняття українців, зокрема, писанка - це великоднє яйце, $\mathrm{a}$, отже, має обрядовий чи релігійний характер, символічними є орнамент і колір, а традиція бере початок з прадавніх часів.

Лексика писанкарства $\epsilon$ досить розгалуженою i надзвичайно різноманітною, що свідчить про самобутність досліджуваного промислу в історичному минулому i до сьогодні, вона має складну внутрішню структуру й на основі взаємодії принципів опозиційного протиставлення і семантичної спільності ділиться на такі групи: 1) назви орнаментів та їх елементів; 2) назви технік у писанкарстві; 3) назви процесуальних понять; 4) назви оздоблених пасхальних яєць за виконанням; 5) агентивні найменування; 6) назв и елементів декорування писанок; 7) назви інструментів та знарядь; 8) назви кольорів; 9) назви виробів 3 писанок; 10) назви ігор та забав, пов'язаних з писанками.

У зв'язку з цим лексику писанкарства можна розглядати у процесі функціонування у спеціальних текстах, можна виявити залежність між формальними, семантичними й стилістичними характеристиками терміна, а також у контексті.

○ Ю. В. Датченко, 2015. 
Українські писанки зберегли значну кількість архаїчних мотивів, композицій i народних назв. Дослідник орнаментики М. Селівачов констатує, що в «писанкарстві найширше серед всіх видів народного мистецтва представлені домінантні мотиви українського орнаменту» [3]. Це «вазони», «дерева», «квіти», «ружі», «сливки», «сорок гілок», «сосонки», «трилисники», «рачки», «рибки», «сороки», «баранячі ріжки» тощо. Зважаючи на регіональні особливості художнього вирішення писанок, можна виокремити найтиповіші для кожного осередку й регіону України мотиви, схеми їхнього розташування, колорит тощо, які мають вербальні характеристики. Так, найвишуканішими за технікою виконання та композиціями є гуцульські писанки, які характерні геометричними, зоо- й антропоморфними мотивами, найбільшою самобутністю декору позначені писанки Поділля й Полісся, де збереглися давні фітоантропоморфні й зооантропоморфні символи з назвами «берегиня», «княгиня», «королева», «панна» та ін.

Аналіз лексики писанкарства допомагає з'ясувати, що до масиву спеціальної лексики входять як однозначні, так і багатозначні лексеми, які грунтуються на метафоричному й метонімічному перенесенні найменувань. Причини виникнення багатьох назв для позначення однієї реалії полягають у популярності й доступності виконання (відсутність потреби у громіздких знаряддях праці), компактність при переміщенні, довільний вибір робочого місця, а також дотримання народних традицій та обрядових ритуалів призводили до того, що писанкарський промисел був масовим. Тому майже кожна писанкарка мала, як правило, не лише свій запас улюблених технік, орнаментів, нерідко створюючи їх, а й власний арсенал прямих і образних найменувань до них.

Найбільшу групу лексики писанкарства складають назви орнаментів та їх елементів, а саме: фітоморфні (квіти, вінки, вазони, гілки, листки, сосонки, ягідки та ін.); скевоморфні (названі за асоціацією з рукотворними предметами) (граблі, гребінчики, вітряки, драбинки, віконця, решітки, ключі, медівники); зооморфні (півні, зозулі, бджілки, метелики, павучки, вужі, гадючки, жабки, заячі вуха, баранячі роги); космогонічні (за асоціацією з астрономічними об'єктами) (сонце, зірки «звізди»). Група абстрагованих поетичних образів названа за асоціацією з міфологічнофольклорними персонажами та метафорами (берегиня, райська пташка, Божа краса, байстрючки, сльоза, сирітка та ін.). Окремими мотивам (круг, кривулька, безкінечник) властива графічна й лексична поліваріантність.

Крім розмаїття орнаментальних знаків і назв, існує їх певна символіка, яка відображає унікальність світосприйняття українців, 
наприклад, «хрест» і його незліченні різновиди, що $є$ найпоширенішим мотивом в писанкарстві символізує «всесвіт, чотири сторони світу, чотири пори року, святий знак відкуплення» [4, с. 387], «пташка - символ єднання земного і небесного, охоронець душ предків, птахи символізують чесноти святих та їх вознесіння до Бога» [4, с. 387].

Отже, лексика писанкарства $\epsilon$ мовно-культурним феноменом, оскільки в ній відображається осмислення світу й сприйняття українцями навколишньої дійсності.

\section{Література}

1. Верещагин Е. М. Лингвострановедческая теория слова / Е. М. Верещагин, В. Г. Костомаров. - М. : Русский язык, 1980. - 320 с.

2. Жайворонок В. В. Знаки української етнокультури : [словник-довідник] / В. В. Жайворонок. - К. : Довіра, 2006. -703 с.

3. Селівачов М. Р. Лексикон української орнаментики : [навчальний посібник] / М. Р. Селівачов. - К. : Редакція вісника «Ант» : Фенікс, 2013. - 413 с.

4. 100 найвідоміших образів української міфології. - К. : Автограф, 2007. - 460 с. Стаття надійшла до редакиії 28.08.2015 p. 